\title{
Prediction of apparent metabolizable energy and metabolizable energy corrected for nitrogen of corn according to physical classification of the grain
}

\section{Sandra lara Furtado Costa Rodrigues ${ }^{1}$, José Henrique Stringhini ${ }^{2}$ (D), Candice Bergmann Tanure $^{3}$ (ID), Vanessa Peripolli ${ }^{4}$ (iD, Luiza Seixas ${ }^{3}$ (iD, Concepta McManus ${ }^{5}$}

\author{
${ }^{1}$ Novus do Brasil, Indaiatuba, SP, Brasil. \\ ${ }^{2}$ Universidade Federal de Goiás, Escola de Veterinária e Zootecnia, Departamento de Zootecnia, Goiânia, GO, Brasil. \\ ${ }^{3}$ Universidade de Brasília, Programa de Pós-graduação em Ciências Animais, Brasília, DF, Brasil. \\ ${ }^{4}$ Instituto Federal Catarinense, Campus Araquari, Araquari, SC, Brasil. \\ ${ }^{5}$ Universidade de Brasilia, Instituto de Biologia, Brasilia, DF, Brasil.
}

\begin{abstract}
The objective of this study was to develop an equation to determine the apparent metabolizable energy (AME) and metabolizable energy corrected for nitrogen balance (AMEn) using a physical-based classification of corn. A total of 5,055 samples were taken from bulk cargo trucks, over a five-year period. The parameters studied were the variables related to the physical characteristics of grains. The density of maize was evaluated, and AME and AMEn were calculated. The average value for AME was 3,375 kcal/kg, and two groups were formed of high quality and low quality for all samples. Stepwise regression analysis was then carried out using grain quality to estimate AME and AMEn, and the validation of the equations was carried out with 6,490 independent samples. The average value for density was $767.7 \mathrm{~kg} / \mathrm{m}^{3}$. The multiple regressions used to estimate AME and AMEn as a function of humidity, density, and physical composition of corn kernels showed that moisture was included for AME, but not for AMEn. The equations presented high coefficients of determination $\left(\mathrm{R}^{2}\right)$ for AME (0.994) and AMEn (0.987). The discriminant analyses correctly classified $98 \%$ of the high-quality samples and $96.69 \%$ of low-quality samples, so the error was smaller than the expected. The calculated equations were shown to be good at discriminating between samples of high and low quality of corn according to its physical composition, and the most important variables for separation between groups were damaged grain fraction, impurities, burnt, and soft. The correlation between calculated (independent samples) and estimated metabolizable energy and AMEn were, respectively, 0.9942 and 0.9859 . The corn energy values can be estimated based on physical evaluation of the grain.
\end{abstract}

Key Words: broilers, metabolizability, nutritional value

\section{Introduction}

Corn (Zea mays L.) is one of the main cereals grown worldwide that provides energy due to its composition of carbohydrates and lipids, being used for animal feed, human consumption, and industry (Matos, 2007). For feed formulation, knowledge of the energy value of feeds is essential to calculate the energy supply to optimize animal performance (Sakomura and Rostagno, 2007).

In practice, it is assumed that the energy value of corn is constant, but the uses of nutrients vary due to various factors, mainly chemical composition (Soto-Salanova et al., 1996). These variations justify the importance of

Received: June 9, 2017

Accepted: December 5, 2017

*Corresponding author: vanessa.peripolli@hotmail.com

Copyright (C) 2018 Sociedade Brasileira de Zootecnia. This is an Open Access article distributed under the terms of the Creative Commons Attribution License (http://creativecommons.org/licenses/by/4.0/), which permits unrestricted use, distribution, and reproduction in any medium, provided the original work is properly cited. understanding the energy values of the feed (Eyng et al., 2009). However, there is little information on the significant variations in the chemical composition and nutritional value of grain, thus hampering the precise formulation of rations (Silva et al., 2011).

The determination of feed energy values used to formulate diets is difficult for the industry because it takes time, infrastructure, and financial resources (Pozza et al., 2008). An indirect way to evaluate the nutritional quality of this raw material is the use of prediction equations including determination of metabolizable energy using chemical and physical parameters of the feed (Eyng et al., 2009; Corte Real et al., 2014). This equation has been an important tool to increase accuracy in the feed formulation process, so energy values can be corrected according to variations in the composition of the feed (Albino and Silva, 1996; Barbarino Junior, 2001), as most chemical analysis of corn and other ingredients used in equations to infer energy values are often not consistent with those measured in metabolic assays (Corte Real et al., 2014). 
Thus, to speed up the correction of the energy value of corn based on its physical characteristics, the objective of this work was to develop an equation to determine AME and AMEn using a physical-based classification of corn.

\section{Material and Methods}

The experiment was conducted in Brasília, Distrito Federal, Brazil, defined by the geographical coordinates $15^{\circ} 46^{\prime} 48^{\prime \prime}$ of South latitude, $47^{\circ} 55^{\prime} 45^{\prime \prime}$ of West longitude, and average altitude of $1.136 \mathrm{~m}$. A total of 5,055 samples were taken from bulk cargo trucks, with a mean of 100 samples per month, over a five-year period. An amount of $30 \mathrm{~kg}$ was collected in the upper, middle, and lower substracts of the truck with total capacity of 30 tonnes, with a minimum quantity of $2 \mathrm{~kg}$ per sampled point (according to Brazilian Federal Regulations; Brasil, 2011). The extracted samples, at least $1 \mathrm{~kg}$ each, were homogenized and divided into four parts ( $250 \mathrm{~g}$ for each sample): two were evaluated by chemical analysis and two stored as counterproof. The removal or extraction of the sample and the classification of grain was carried out according to Brazilian Federal Regulations (Brasil, 2011).

The parameters studied were the variables related to physical characteristics, especially damage, in grams per 100 grams of corn, such as grains considered strange, impurity, and foreign grains: normal grains which passes readily through a 12/64-inch or 5-mm round-hole sieve, being considered the impurities of the own product or seeds of other species, as well as plant debris, dirt, and foreign matter of any nature, not originated from the product; broken grains: the pieces of normal grains that were retained in the 12/64-inch or 5-mm round-hole sieve and normal grains missing small parts or containing small flakes; soft or immature grains: grain devoid of internal mass, stiffened, and wrinkled by incomplete physiological development; grains damaged by beetles: grains attacked by beetles, but without the presence of live insects; grains damaged by fungi and derivates: whole or broken grains that present fungus (mold) in whole or in part; sour grain: grains that have lost color characteristic by the action of heat and moisture or fermentation in more than a quarter of the grain size; fermented grains: grains with dark spots of any size up to a quarter of the grain area, corresponding approximately to the germ area; grains damaged by various causes: whole or broken grains considered as defective, which present alteration in the integument or mass due to mechanical, physical, or biological causes; grains injured by other causes: the sum of the several defects mentioned in the other categories; grits: normally developed grains that have good maturity and conservation conditions; density in grams per liter and humidity, all expressed in percentage.

Grains were grouped following the classifications defined in Barbarino Junior (2001). Moldy grains included burnt, fermented, and moldy; fragmented included impurities, fragmented, and grits; insects were mainly beetles; broken grains; and damaged included soft, those attacked by rodents, pests, parasites, and others not included above. The grains considered as good were obtained by the difference of the entire sum of all the physically damaged grains above.

The density of corn was evaluated using the methodology of the test weight, in which the products are distinguished by gravity table, which stratifies the cereal by the density or the specific weight.

Apparent metabolizable energy and AMEn related to the corn physical characteristics (Table 1) were obtained from a digestibility trail (Costa et al., 2015) and calculated according to Matterson et al. (1965):

AME $(\mathrm{kcal} / \mathrm{kg})=\mathrm{CE}-\mathrm{Ceexc} /$ dry matter intake (Equation 1) and AMEn $(\mathrm{kcal} / \mathrm{kg})=\mathrm{CE}-\mathrm{Ceexc}+8.22 * \mathrm{NB} /$ dry matter intake (Equation 2),

in which $\mathrm{CE}=$ crude energy intake; Ceexc = crude energy excreted; and $\mathrm{NB}=$ nitrogen balance (intake nitrogenexcreted nitrogen).

Based on the above physical analysis and metabolizable energy values from sample components, depending on the proportion of each type of grain found in the 5,055 samples, AME and AMEn were calculated for the full grain sample, according to the categories used by Barbarino Junior (2001):

$\operatorname{AME}(\mathrm{kcal} / \mathrm{kg})=[(\%$ Good $* 3,381)+(\%$ Broken*3,353)

$+(\%$ Fermented*3,334) $+(\%$ Insect*3,176) $+(\%$ Burnt/

Moldy*3,290) + (\%Damaged*3,353)]/100 (Equation 3);

AMEn $(\mathrm{kcal} / \mathrm{kg})=[(\%$ Good*3,310 $)+(\%$ Broken*3,290)

$(\%$ Fermented*3,266) $+(\%$ Insect*3,122) +

$(\%$ Moldy*3,244) $+(\%$ Damaged $* 3,290)] / 100$ (Equation 4$)$.

The average value for AME of all samples was $3,375 \mathrm{kcal} / \mathrm{kg}$.

Table 1 - Apparent metabolizable energy (AME) and apparent metabolizable energy corrected for nitrogen balance (AMEn) as-fed basis $(\mathrm{kcal} / \mathrm{kg})$, related to the corn physical characteristics

\begin{tabular}{lcc}
\hline Physical variable & $\begin{array}{c}\text { AME } \\
\text { (kcal/g as-fed basis })\end{array}$ & $\begin{array}{c}\text { AMEn } \\
\text { (kcal/g as-fed basis })\end{array}$ \\
\hline Broken grain & 3.353 & 3.290 \\
Fragmented grain & 3.353 & 3.290 \\
Burnt/moldy grain & 3.290 & 3.244 \\
Fermented grain & 3.334 & 3.266 \\
Insects & 3.176 & 3.122 \\
Damaged & 3.353 & 3.290 \\
Good & 3.381 & 3.310
\end{tabular}


Two groups were formed in the cluster analysis of high-quality and low-quality samples. Stepwise regression analysis was then carried out using grain quality (fractions, humidity, and density) to estimate AME and AMEn. A significance level of $1 \%$ for each variable was adopted. The final equations considered only variables that presented significance. The validation of the equations in the present study was carried out by comparing the AME and AMEn estimated values with AME and AMEn values calculated using Eqations 3 and 4 from 6,490 independent samples. Results from Equations 3 and 4 were compared with the values obtained using the equations developed in this work, based on their metabolizable energy values using correlations (PROC CORR).

A canonical discriminant analysis was performed to determine the most important traits in the classification of variables within the two quality groups.

Outliers (3 SD) were deleted for each variable individually. Residuals were tested for normality and found not to differ from the normal, probably because of the large number of data in each variable. Analyses were carried out using SAS software (Statistical Analysis System, version 9.3).

\section{Results}

The average value obtained through the equations for density was $767.7 \mathrm{~kg} / \mathrm{m}^{3}$ and ranged between $628 \mathrm{~kg} / \mathrm{m}^{3}$ and $895 \mathrm{~kg} / \mathrm{m}^{3}$ (Table 2).

The equations from the multiple regressions used to estimate AME and AMEn (Table 3 ) as a function of humidity, density, and physical composition of corn kernels showed that moisture was included for AME, but not for AMEn.

Table 2 - Means, standard deviations (SD), and minimum (Min) and maximum (Max) values obtained for 5,055 corn samples used in equation development

\begin{tabular}{lcccc}
\hline Trait & Mean & SD & Minimum & Maximum \\
\hline Density (kg/m $\left.{ }^{3}\right)$ & 767.7 & 26.00 & 628.00 & 895.00 \\
Humidity (\%) & 12.75 & 1.72 & 10.08 & 16.00 \\
Good (\%) & 88.41 & 3.13 & 67.00 & 98.12 \\
Broken (\%) & 4.63 & 1.36 & 0.00 & 1.54 \\
Fragments (\%) & 1.95 & 0.96 & 0.00 & 10.40 \\
Impurities (\%) & 0.27 & 0.29 & 0.00 & 5.56 \\
Burnt (\%) & 0.14 & 0.29 & 0.00 & 13.00 \\
Moldy (\%) & 0.00 & 0.04 & 0.00 & 2.00 \\
Sour (\%) & 2.83 & 1.11 & 0.00 & 10.05 \\
Fermented (\%) & 0.88 & 0.57 & 0.00 & 5.14 \\
Infected by insects (\%) & 0.13 & 0.24 & 0.00 & 6.12 \\
Soft (\%) & 0.16 & 0.18 & 0.00 & 8.00 \\
Damaged (\%) & 0.60 & 0.54 & 0.00 & 5.05 \\
Foreign material (\%) & 0.05 & 0.13 & 0.00 & 4.00 \\
Injured (\%) & 9.23 & 2.47 & 0.00 & 24.39 \\
\hline
\end{tabular}

The equations presented high coefficients of determination $\left(\mathrm{R}^{2}\right)$ for AME (0.994) and AMEn (0.987), which indicate an excellent fit to the data. The discriminant analyzes correctly classified $98 \%$ of the high-quality samples and $96.69 \%$ of low-quality samples, so the error was smaller than the expected (Table 4).

Thus, the calculated equations were shown to be good at discriminating between samples of high and low quality of corn according to its physical composition (Table 5).

Table 3 - Equations from the multiple regression to estimate AME and AMEn as a function of density, moisture, and physical composition of corn kernels

\begin{tabular}{lcc}
\hline & AME & AMEn \\
\hline Intercept & 3310.06292 & 3381.18478 \\
Density & -0.00013085 & -0.00027 \\
Broken & -0.19867 & -0.27963 \\
Fragmented & -0.20547 & -0.28623 \\
Moldy/burnt & -0.60084 & -0.79110 \\
Insect & -1.88072 & -2.06007 \\
Injured & -0.22810 & -0.29799 \\
Humidity & $\mathrm{NS}$ & -0.232 \\
$\mathrm{R}^{2}$ & 0.994 & 0.987 \\
\hline
\end{tabular}

AME - estimate the apparent metabolizable energy; AMEn - apparent metabolizable energy corrected for nitrogen balance; NS - not significant; $\mathrm{R}^{2}$ - coefficient of determination.

Table 4 - Percentage of samples classified in high- (HQ) and lowquality (LQ) groups using discriminant functions

\begin{tabular}{lccc}
\hline \multirow{2}{*}{ Group } & \multicolumn{3}{c}{ Group classification } \\
\cline { 2 - 4 } & HQ & LQ & No. of samples \\
\hline HQ & 98.06 & 1.94 & 2,635 \\
LQ & 3.31 & 96.69 & 2,420 \\
Error & 0.02 & 0.03 & 5,055 \\
Prior error expectation & 0.50 & 0.50 & \\
\hline
\end{tabular}

Table 5 - Discriminant analysis coefficients for corn physical parameters for high- and low-quality grains

\begin{tabular}{lcc}
\hline \multirow{2}{*}{ Variable } & \multicolumn{2}{c}{ Group } \\
\cline { 2 - 3 } & High quality & Low quality \\
\hline Constant & -521.65911 & -536.31773 \\
Density & 1.13555 & 1.13244 \\
Humidity & 10.11671 & 10.39806 \\
Broken & 3.05915 & 3.25655 \\
Fragmented & 2.94883 & 2.99657 \\
Impurities & 16.9886 & 26.50723 \\
Burnt & 22.65568 & 34.00288 \\
Moldy & -11.02629 & -9.22456 \\
Sour & 3.81331 & 4.0943 \\
Fermented & 7.40845 & 7.79502 \\
Infected by beetles & 1.30763 & 1.65086 \\
Soft & 1.76299 & 2.63130 \\
Damaged & 4.2571 & 14.1451 \\
Foreign matter & 8.69903 & 430.748 \\
Injured & -0.09064 & 0.02584 \\
\hline
\end{tabular}


The most important variables for separation between groups were damaged grain fractions, impurities, burnt, and softness (Table 6). The fractions of moldy, fragmented, fermented, infected by beetles, and good grains had little effect on the differences among the groups.

Correlations using the independent samples using the equations proposed in Table 3 and those in Equations 3 and 4 for metabolizable energy and AMEn were, respectively, 0.9942 and 0.9859 .

\section{Discussion}

An indirect way to assess the nutritional quality of corn is the use of prediction equations. Most equations use chemical analyzes to infer AMEn value for corn and other ingredients, often with inconsistent values measured in metabolism assays. An alternative to this type of equation is predictions involving the density, humidity, and classification of the grain.

The average values for the density described by Rodrigues et al. (2001) ranged between 724.5 and $757.7 \mathrm{~kg} / \mathrm{m}^{3}$, being lower than the average values obtained in this study $\left(767.7 \mathrm{~kg} / \mathrm{m}^{3}\right)$. The variation obtained by the previous researchers showed less variation between the minimum and maximum values than those found in this study $\left(628 \mathrm{~kg} / \mathrm{m}^{3}\right.$ to $\left.895 \mathrm{~kg} / \mathrm{m}^{3}\right)$.

Silva et al. (2008) evaluated the nutritional value of different corn quality for broilers and concluded that the percentage of broken, rancid, infected by beetles, and hollow grains, impurities/fragments, and foreign material increased as the density of maize grains studied decreased. Silva et al. (2011) also reported loss increase when corn quality decreases, and, to make corrections, they suggested the evaluation of corn quality according to the classification of grains. The average humidity was $12.75 \%$ and met the specifications for corn type 1 (maximum limit of $14 \%$; Brasil, 2011).

Table 6 - Standardized canonical analysis for separation of groups

\begin{tabular}{lc}
\hline Variable & Coefficient \\
\hline Broken & 0.12641 \\
Fragmented & 0.00761 \\
Impurities & 0.60269 \\
Burnt & 0.36558 \\
Moldy & 0.02942 \\
Sour & 0.14109 \\
Fermented & 0.08348 \\
Infected by beetles & 0.02033 \\
Soft & 0.28777 \\
Damaged & 1.10086 \\
Good & 0.00000 \\
\hline
\end{tabular}

The average score for the total injured corn, which includes other physical fractions analysed, except the good grains, was $11.64 \%$, value that would meet the standard specification for corn type 3 (maximum limit is $15 \%$ ); however, when considering the maximum value obtained from the samples of $24.39 \%$, the corn would be classified as unusable, as the maximum limit is 20\% (Brasil, 2011).

Equations with many variables, although providing more accurate estimates, may be unfeasible, since the determination of components such as chemical analysis and all the grain damages under practical conditions is often difficult to measure. Thus, the use of equations with fewer variables are more easily used in low-complexity analysis, especially those carried out in routine laboratory analysis, requiring less time and showing ease of determination (Nunes et al., 2001).

The fraction of grains damaged by insects was the variable that most affected the energy values of the two equations and correlated negatively with the energy content of the corn. The proliferation of insects and mold growth are closely associated with the reduction of nutrients such as lipids, carbohydrates, minerals, proteins, and vitamins, which reduces the performance and health of the animals (Brucato et al., 1986).

Barbarino Junior (2001) showed, in a canonical analysis, that the occurrence of fungal and insect attacks resulted in losses in the ether extract, starch, and sugars in the grains. Dale and Jackson (1994) observed that broken corn kernels and strange matter significantly reduced the value of true metabolizable energy for poultry by 5.6 and $17.0 \%$, respectively.

The average values of AME found in this work was $3,375 \mathrm{kcal} / \mathrm{kg}$. This finding is consistent with those observed by Eyng et al. (2009), who found 3,227 to $3,416 \mathrm{kcal} / \mathrm{kg}$ for $\mathrm{AME}$ in eight different corn varieties. Low-quality grains showed more damage, more problems such as fragmented, broken, and grains infected by beetles, but little difference in density. The results of physical composition and grain moisture affected the corn chemical and energy content, as demonstrated by Rodrigues et al. (2014), Costa et al. (2015), and Hruby (2015), as corn hybrids and broiler age of determination can affect the energy content, similar to the observed in the experiment conducted by Kato et al. (2011).

The prediction equations should be validated to be considered reliable (Dale et al., 1990). In addition, the NRC (1994, 1998) pointed out few studies comparing the estimated and chemically determined or validate equations under different conditions to those in which they were developed. Since corn groups were defined as different 
from each other of these relations, within each group, the correction proposed by the equation can also be performed, which is a form to validate its use (Table 3). It is possible to note that one of the main steps in this process is the validation of the proposed equations, by comparing the estimate values with independent ones.

Silva et al. (2008), comparing the results obtained in the metabolism assay with those obtained by the equation of Baidoo et al. (1991) for estimating the energy value according to the density and dry matter, found 3,462, 3,187, and $2,574 \mathrm{kcal} / \mathrm{kg}$ for the high (MDA), intermediate (MDI), and low (MDB) density, respectively. The results were similar to those found in the metabolism assay for the MDA, which was inferior to MDI and MDB by approximately 300 and $700 \mathrm{kcal} / \mathrm{kg}$, respectively. The equation evaluated by the authors estimated the best energy value of goodquality corn and underestimated the value of lower-quality corn. According to Albino et al. (1992), the importance of determining prediction equations for the energy value of feed is necessary due to the difficulty in performing bioassays and to the fact that most laboratories do not have a calorimeter. In this case, working with equations generated from physical and routine-quality control laboratories, these results in simple equations can help the nutritionist.

\section{Conclusions}

Based on these data, the proposed equation is valid to estimate the corn energy values according to the physical quality of the grain.

\section{Acknowledgments}

The authors thank Coordenação de Aperfeiçoamento de Pessoal do Ensino Superior (CAPES), for the financial support, and ASA Alimentos and Nutron, for the techinical support.

\section{References}

Albino, L. F. T.; Rostagno, H. S.; Fonseca, J. B. and Torres, R. A. 1992. Utilização de diferentes sistemas de avaliação energéticas dos alimentos na formulação de rações para frangos de corte. Revista da Sociedade Brasileira de Zootecnia 21:1037-1046.

Albino, L. F. T. and Silva, M. A. 1996. Valores nutritivos de alimentos para aves e suínos determinados no Brasil. p.303-318. In: Simpósio Internacional sobre Exigências Nutricionais de Aves e Suínos, Universidade Federal de Viçosa, Viçosa, MG, Brasil.

Baidoo, S. K.; Sheres, A. and Roblee, A. R. 1991. Effect of kernel density on the apparent and true metabolizable energy value of corn for chikens. Poultry Science 70:2102-2107. https://doi.org/10.3382/ps.0702102
Barbarino Junior, P. 2001. Avaliação da qualidade nutricional do milho pela utilização de técnicas de análise uni e multivariadas. Tese (D.Sc). Universidade Federal de Viçosa, Viçosa, MG, Brasil.

Brasil. 2011. Instrução Normativa $N^{\circ} 60$, de 22 de dezembro de 2011, do Ministério da Agricultura, Pecuária e Abastecimento. Regulamento Técnico do Milho. Diário Oficial da União, Brasília, DF, 23 dez 2011.

Brucato, M.; Sundlof, S. F.; Bell, J. U. and Edds, G. T. 1986. Afltoxin $\mathrm{Bi}$ toxicosis in dairy calves pretreated with selenium-vitamin E. American Journal of Veterinary Research 47:179-183.

Corte Real, G. S. C. P.; Couto, H. P.; Matos, M. B.; Lyra, M. S.; Gomes, A. V. C. and Ferreira, S. R. R. 2014. Nutritional values of corn with different qualities for egg pullets in the growing phase. Arquivo Brasileiro de Medicina Veterinária e Zootecnia 66:546-554. https://doi.org/10.1590/1678-41625929

Costa, S. I. F. R.; Stringhini, J. H.; Ribeiro, A. M. L.; Pontalti, G. and MacManus, C. 2015. Utilization of different corn fraction by broilers. Revista Brasileira de Ciência Avícola 12:307-312. https://doi.org/10.1590/1516-635X1703307-312

Dale, N. and Jackson, D. 1994. True metabolizable energy of corn fractions. The Journal of Applied Poultry Research 3:179-183. https://doi.org/10.1093/japr/3.2.179

Dale, N. M.; Pesti, G. M. and Rogers, S. R. 1990. True metabolizable energy of dried bakery product. Poultry Science 69:72-75. https://doi.org/10.3382/ps.0690072

Eyng, C.; Nunes, R. V.; Pozza, P. C.; Pozza, M. S. S.; Nunes, C. G. V.; Navarini, F. C.; Silva, W. T. M. and Appelt, M. D. 2009. Composição química e valores energéticos de cultivares de milhos para aves. Revista Brasileira de Saúde e Produção Animal 10:60-72.

Hruby, M. 2015. Corn nutritive value key to improved profitability. Feedstuffs 86:1-3.

Kato, R. K.; Bertechini, A. G.; Fassani, E. J.; Brito, J. A. G.; Castro, S. F. 2011. Metabolizable energy of corn hybrids for broiler chickens at different ages. Ciência e Agrotecnologia 35:1218-1226. https://doi.org/10.1590/S1413-70542011000600024

Matos, E. H. S. F. 2007. Plantação do milho verde. Universidade de Brasília, Brasília, DF.

Matterson, L. D.; Potter, L. M.; Stutz, M. W. and Singsen, E. P. 1965. The metabolizable energy of feed ingredients for chickens. Agricultural Experimental Station Research Report 7:3-22.

NRC - National Research Council. 1994. Nutrient requirements of poultry. National Academy Press, Washington, DC.

NRC - National Research Council. 1998. Nutrient requirements of poultry. National Academy Press, Washington, DC.

Nunes, R. V.; Rostano, H. S.; Albino, L. F. T.; Gomes, P. C. and Toledo, R. S. 2001. Chemical composition, metabolizable energy and energy prediction equations of wheat grain and wheat by-products for broiler chicks. Revista Brasileira de Zootecnia 30:785-793. https://doi.org/10.1590/S1516-35982001000300025

Pozza, P. C.; Gomes, P. C.; Donzele, J. L.; Rostagno, H. S.; Pozza, M. S. S. and Nunes, R. V. 2008. Composição química, digestibilidade e predição dos valores energéticos da farinha de carne e ossos para suínos. Acta Scientiarum Animal Sciences 30:33-40. https://doi.org/10.4025/actascianimsci.v30i1.3597

Rodrigues, P. B.; Rostagno, H. S.; Albino, L. F. T.; Gomes, P. C.; Barboza, W. A. and Santana, R. T. 2001. Valores energéticos do milheto, do milho e subprodutos do milho, determinados com frangos de corte e galos adultos. Revista Brasileira de Zootecnia 30:1767-1778. https://doi.org/10.1590/S1516-35982001000700015

Rodrigues, S. I. F. C.; Stringhini, J. H.; Ribeiro, A. M. L.; Pontalti, G. C. and McManus, C. M. 2014. Quality assessment of corn batches received at a feed mill in the Brazilian cerrado. Revista Brasileira de Ciência Avícola 16:233-240. https://doi.org/10.1590/1516-635x1603233-240 
Sakomura, N. K. and Rostagno, H. S. 2007. Métodos de pesquisa em nutrição de monogástricos. Funep, Jaboticabal.

Silva, C. S.; Couto, H. P.; Ferreira, R. A.; Fonseca, J. B.; Gomes, A. V. C. and Soares, R. T. R. N. 2008. Valores nutricionais de milhos de diferentes qualidades para frangos de corte. Revista Brasileira de Zootecnia 37:883-889. https://doi.org/10.1590/S1516-35982008000500016
Silva, C. S.; Menten, J. F.; Traldi, A. B.; Santarosa, J. and Pereira, P. W. Z. 2011. Avaliação de milhos de diferentes densidades para frangos de corte. Revista Brasileira de Zootecnia 40:1554-1561. https://doi.org/10.1590/S1516-35982011000700022

Soto-Salanova, M. F.; Garcia, O.; Graham, H. and Pack, M. 1996. Uso de enzimas em dietas de milho e soja para frangos de corte. In: Conferência Apinco de Ciência e Tecnologia Avícolas, Curitiba. 